\title{
SOME OF THE VERIFICATION RESULTS OF THE USE BOX OF BRICKS FOR THE PUPILS AT PRIMARY SCHOOL (AGE GROUP 10-15 YEARS OLD)
}

\section{Ludovít POL $\check{C I C}$}

\begin{abstract}
In this article the author sets aims, the subject and hypothesis of the research, sample group and research methodology. Author is characterizing and explaining the results of hypothesis's verification H3. In this hypothesis he claims that the pupils at primary schools (age group 10-15), who used a box of bricks 'Dominika', will gain better results than pupils taught in ordinary control group at the end of experimental teaching process; in Test of Differentiation of Abilities.
\end{abstract}

Keywords: pedagogical research, pedagogical experiment, box of bricks, control group, experimental group, didactic tests, statistic verification.

\section{NIEKTORÉ VÝSLEDKY Z OVEROVANIA STAVEBNICE V PODMIENKACH NIŽŠIEHO SEKUNDÁRNEHO VZDELÁVANIA}

Resumé: V článku autor uvádza ciele, predmet, hypotézy výskumu, výberovú vzorku a metodiku výskumu. V príspevku interpretuje avysvetluje výsledky verifikácie hypotézy $H 3, v$ vtorej predpokladá, že žiaci na 2. stupni ZŠ, ktorí použivali stavebnicu Dominika, dosiahnu na konci experimentálneho vyučovania v Teste diferenciácií schopností - priestorové vzt'ahy vyšši výkon ako žiaci vyučovani tradične $v$ kontrolnej skupine.

Kl'účové slová: pedagogický výskum, pedagogický experiment, stavebnica, kontrolná skupina, experimentálna skupina, didaktické testy, štatistická verifikácia.

\section{1 Úvod}

Teória tvorivo-humanistickej výchovy požaduje budovat' vysokomotivačný vzt'ah žiaka k učeniu, učitel'ovi, škole, poznávaniu, vzdelaniu. Humanizácia vzt’ahov žiak - učitel', žiak - učivo sa dosahuje interaktívnymi komunikačnými metódami. Ako jednu z možností vidíme využívanie hračiek ako didaktických prostriedkov vo vyučovacom procese. V školskej edukácii majú hračky opodstatnenie v zmysle postulátu, že hra a učenie nie sú $v$ protiklade. Existuje pre to niekol'ko dôvodov. Jedným z nich je ponímanie hračiek ako edukačných médií použitelných temer v každom predmete. Stavebnice spĺnajú všetky funkcie učebných pomôcok: motivačnú, spätnoväzobnú, informačnú, precvičovaciu, aplikačnú, kontrolnú, výchovnú, rozvíjajúcu, racionalizačnú. Aj z týchto dôvodov sme sa rozhodli navrhnút', vyhotovit' a overit' multifunkčnú hračku - stavebnicu Dominika ako učebnú pomôcku, $v$ reálnych podmienkach základnej školy.

\section{Ciele a hypotézy výskumu}

Ciel'om empirického výskumu bolo overenie úspešnosti použitia stavebnice Dominika $\mathrm{v}$ reálnych podmienkach vybraných škôl v predmete Technická výchova.

K splneniu tohto ciel'a boli sformulované nasledujúce úlohy:

1. Navrhnút' a vyhotovit' stavebnicu ako didaktický prostriedok na rozvoj tvorivého technického myslenia žiakov.

2. Na základe výsledkov vstupného testu určit' kontrolnú a experimentálnu skupinu žiakov 6. ročníka.

3. Použit' stavebnicu vo vyučovacom procese $\mathrm{v}$ experimentálnej skupine $\mathrm{v}$ tematickom celku Princípy zobrazovania $\mathrm{v}$ témach Základy technického zobrazovania, pravouhlé premietanie na tri premietne, čítanie a kreslenie jednoduchých technických náčrtov a výkresov v 6. ročníku základných škôl.

4. Vyhodnotit' výsledky v kontrolnej a v experimentálnej skupine.

5. Formulovat' závery a odporúčania. 
$\mathrm{Na}$ splnenie stanovených úloh navrhujeme overenie hlavnej hypotézy $\mathrm{H}$.

H: Pri plnení ciel'ov technickej výchovy sú predpoklady na efektívne využívanie hračky - stavebnice Dominika na základných školách.

Aby bolo možné hypotézu kvantitatívne a kvalitatívne verifikovat', sformulovali sme nasledovné pracovné hypotézy:

H1: Žiaci, ktorí použivali stavebnicu Dominika, dosiahnu na konci experimentálneho vyučovania vo vedomostnom didaktickom teste vyšší výkon v oblasti zapamätania a špecifického transferu ako žiaci vyučovaní tradične v kontrolnej skupine.

H2: Žiaci, ktorí používali stavebnicu Dominika, dosiahnu na konci experimentálneho vyučovania v praktickom didaktickom teste vyšší výkon v oblasti špecifického transferu ako žiaci vyučovaní tradične $\mathrm{v}$ kontrolnej skupine.

H3: Žiaci, ktorí používali stavebnicu Dominika, dosiahnu na konci experimentálneho vyučovania $\mathrm{v}$ Teste diferenciácií schopností - priestorové vzt’ahy vyšší výkon ako žiaci vyučovaní tradične v kontrolnej skupine.

H4: Žiaci pri preberaní tematického celku Princípy zobrazovania budú uprednostňovat' prácu s učebnicou a zároveň so stavebnicou Dominika ako prácu len s učebnicou.

H5: Uprednostňovanie práce s učebnicou a zároveň s hračkou Dominika bude rovnaké, bez ohl'adu na predmet - teda aj pri Technickej výchove aj pri Výtvarnej výchove.

\section{Predmet, výberová vzorka a metodika výskumu}

Predmetom výskumu dizertačnej práce bola vhodnost' hračky - stavebnice ako didaktického prostriedku rozvíjania tvorivého technického myslenia a jej využívania $\mathrm{v}$ edukačnom procese žiakmi 6. ročníka základných škôl v predmete Technická výchova. Výberový súbor tvorilo 140 žiakov 6. ročníka základných škôl z piatich ZŠ v Slovenskej republike. Ako lokalitu sme určili oravský región. V ňom sme vybrali niekol'ko lokalít pričom sme museli brat' do úvahy aj možnosti spolupráce s pedagógmi škôl. Z tohto hl'adiska je možno hovorit' o pseudonáhodnom výbere lokalít v regióne. Aby sme mohli objektívne určit', či stavebnica Dominika (nezávisle premenná) ovplyvňuje úroveň technického tvorivého myslenia žiakov 6. ročníka základných škôl v predmete Technická výchova, boli do experimentu zahrnuté dve skupiny respondentov: kontrolná a experimentálna. Kontrolnú skupinu tvorilo 70 žiakov a experimentálnu skupinu tvorilo 70 žiakov.

\section{Metodika výskumu}

$\mathrm{Na}$ overenie platnosti stanovenej hlavnej hypotézy a overenie pracovných hypotéz sme zvolili nasledovnú metodiku a organizáciu výskumu, ktoré budú bližšie charakterizovat' predmet výskumu, výber vzorky, metódy, časový harmonogram a organizáciu výskumu. Základnou metódou v prípravnej časti vedecko - výskumnej činnosti bola literárna metóda, pretože predpokladom dôsledného oboznámenia sa sproblematikou hračiek a technického tvorivého myslenia bol dostatok základných informácií získaných štúdiom z odbornej literatúry.

Metódu obsahovej analýzy sme použili na získanie potrebných informácií z platných školských dokumentov.

Úroveň vedomostí a technického myslenia žiakov 6. ročníka základných škôl, sme preverovali pomocou didaktického testu. Didaktický test na zistenie úrovne vedomostí a technického myslenia bol vlastnej konštrukcie. Na začiatku experimentu sme použili vstupný (pretest) a na konci experimentu výstupný test (posttest). Konštrukcia didaktického testu bola konzultovaná s učitel'mi technickej výchovy, ktorí spolupracovali na experimente. Pri konštrukcii položiek $\mathrm{v}$ didaktických testoch sme vychádzali zo Vzdelávacieho štandardu $\mathrm{s}$ exemplifikačnými úlohami $\mathrm{z}$ technickej výchovy pre 2. stupeň základnej školy, schváleným Ministerstvom školstva Slovenskej republiky dňa 4. februára 2002.

$\mathrm{Na}$ zistenie úrovne špecifických schopností - priestorovej predstavivosti žiakov 6. ročníka základných škôl, sme použili štandardizovaný Subtest Priestorové vzt'ahy (PV) z batérie testov diferenciácie schopností (TDS). Na začiatku experimentu sme použili vstupný (pretest) a na konci experimentu výstupný test (posttest).

Úroveň tvorivého technického myslenia žiakov 6. ročníka základných škôl sme zist'ovali 
pomocou tzv. praktického testu. Praktický test bol použitý len na konci pedagogického experimentu.

$\mathrm{Na}$ overenie verifikácie hlavnej hypotézy a pracovných hypotéz sme navrhli nasledovné metódy pedagogického výskumu:

1. Prirodzený pedagogický experiment hlavná metóda výskumu.

2. Metóda obsahovej analýzy pedagogických dokumentov.

3. Didaktické testy - na overovanie hypotéz $\mathrm{H} 1, \mathrm{H} 2, \mathrm{H} 3$.

4. Dotazník - na overenie hypotézy H4, H5.

5. Štatistické metódy na spracovanie výsledkov výskumu - na overenie výsledkov pracovných hypotéz 1. - 5.

Všetky výsledky zistené vo výskume boli vyhodnotené štatistickými metódami v programe SPSS/PC+.

Prirodzený pedagogický experiment bol realizovaný s ciel'om dokázat', že používaním stavebnice Dominika vo vyučovaní predmetu Technická výchova na 2. stupni základných škôl (ZŠ) sa štatisticky významne zlepší úroveň vedomostí, technického myslenia, tvorivého myslenia a priestorovej predstavivosti žiakov v experimentálnych skupinách.

\section{Subtest Priestorové vzt'ahy z batérie Testov diferenciácie schopností}

Úroveň priestorovej predstavivosti sme zist'ovali na začiatku a na konci pedagogického experimentu pomocou štandardizovaného didaktického testu.

$\mathrm{Na}$ zist'ovanie úrovne technického myslenia $\mathrm{v}$ oblasti priestorového faktora $(\mathrm{S}$ faktor $=$ Spatial = priestorová predstavivost'), nám najviac vyhovoval Test diferenciácie schopností. Upravil: R. Kohoutek;

Vydal: Psychodiagnostické a didaktické testy, n.p., Bratislava

Ciel'om autorov batérie Testov diferenciácie schopností (TDS) G. K. Bennetta, H. G. Seashorea a A. G. Wesmana bolo vypracovat' súhrnné a dobre štandardizované postupy na meranie schopností žiakov. Prednost'ou TDS je, že ich konštrukcia sa založila najmä na empirických výskumoch. TDS nevychádzajú explicitne z faktorovej analýzy, aj ked' je zrejmé, že ich autori boli dôkladne oboznámení $\mathrm{s}$ výsledkami tejto metódy. Test Priestorové vzt'ahy (PV) je jedným z 8 testov batérie TDS. Tento test sa skladá zo šest'desiatich plášt'ov, ktoré je možné poskladat' do telies. Pri každom plášti sú štyri telesá. Žiaci majú rozhodnút', ktoré $\mathrm{z}$ týchto telies je možné zložit' $\mathrm{z}$ daného plášt’a. Typy úloh, ktoré test Priestorové vzt'ahy obsahuje, predstavujú kombináciu dvoch prístupov, ktoré sa pri meraní tejto schopnosti používajú. Schopnost' jasne si predstavit' objekt podl'a výkresu sa často používa $\mathrm{v}$ testoch štrukturálnej vizualizácie. Podobne schopnost' predstavit' si ako bude objekt vyzerat', ked' sa rozličným spôsobom obráti, vyžaduje priestorové vnímanie.

Úlohy, ktoré sa v teste PV používajú, sú kombináciou týchto úloh, pretože oba faktory sa ukázali dôležité vo všetkých primeraných definíciách schopnosti mysliet' v priestorových termínoch. Charakteristickou črtou tohto testu je, že úlohy vyžadujú mentálnu manipuláciu $\mathrm{s}$ predmetmi $\mathrm{v}$ trojdimenzionálnom priestore. Také formy úloh, ktoré používajú iba dve dimenzie, sú menej vhodné, ked’že je iba málo prípadov, kedy je dôležitá percepcia v dvojdimenzionálnom priestore. Test PV je mierou schopnosti zaoberat' sa vizuálne konkrétnym materiálom. Jestvuje mnoho povolaní i druhov štúdia, v ktorých sa vyžaduje schopnost' predstavit' si, ako bude predmet vyzerat', ak sa zhotoví podl'a daného náčrtu, alebo ako sa bude objekt javit', ked' sa otočí. Test hodnotí schopnost' mentálne manipulovat' s predmetmi a podl'a plánu vytvorit' v mysli štruktúru. Test Priestorové vzt'ahy sa vyhodnocuje manuálne. Skóre testu je počet správnych odpovedí; nie je tu teda korektúra náhodných riešení. V teste sa pri každej úlohe povol'uje iba jedna odpoved'. Maximálny počet bodov, ktorý môže žiak získat' je 60 . Ukážku úloh uvádzame na obrázku č. 1.

Reliabilita TDS - PV Cronbachovo $\alpha=$ 0,9335 .

\section{Štatistické metódy spracovania výsledkov výskumu}

Testovanie normality: Kolmogorov Smirnovov test v Lillieforsovej modifikácii.

Porovnanie kontrolnej skupiny a experimentálnej skupiny $\mathrm{V}$ preteste a postteste: Vedomostný test, TDS-PV, Praktický test: Kolmogorov-Smirnovov test pre dva nezávislé výbery.

Porovnanie percent odpovedí v jednotlivých položkách: Test rozdielu dvoch relatívnych početností podl'a Reisenaura (k rovnakým výsledkom vedie test chí kvadrát) 
Dotazník pre žiakov: Wilcoxonov test pre dva závislé výbery.

Korelačná analýza: procedúra SPSS/PC+

Reliabilita: procedúra $\mathrm{SPSS} / \mathrm{PC}+$; Cronbachovo $\alpha$

\section{4 Štatistická verifikácia hypotézy H3}

Tret'ou testovanou hypotézou bola hypotéza H3: Žiaci, ktorí používali stavebnicu Dominika, dosiahnu na konci experimentálneho vyučovania v Teste diferenciácí́ schopností priestorové vzt’ahy vyšší výkon ako žiaci vyučovaní tradične v kontrolnej skupine. Štatistické metódy spracovania výsledkov výskumu

Testovanie normality: Kolmogorov Smirnovov test v Lillieforsovej modifikácii.

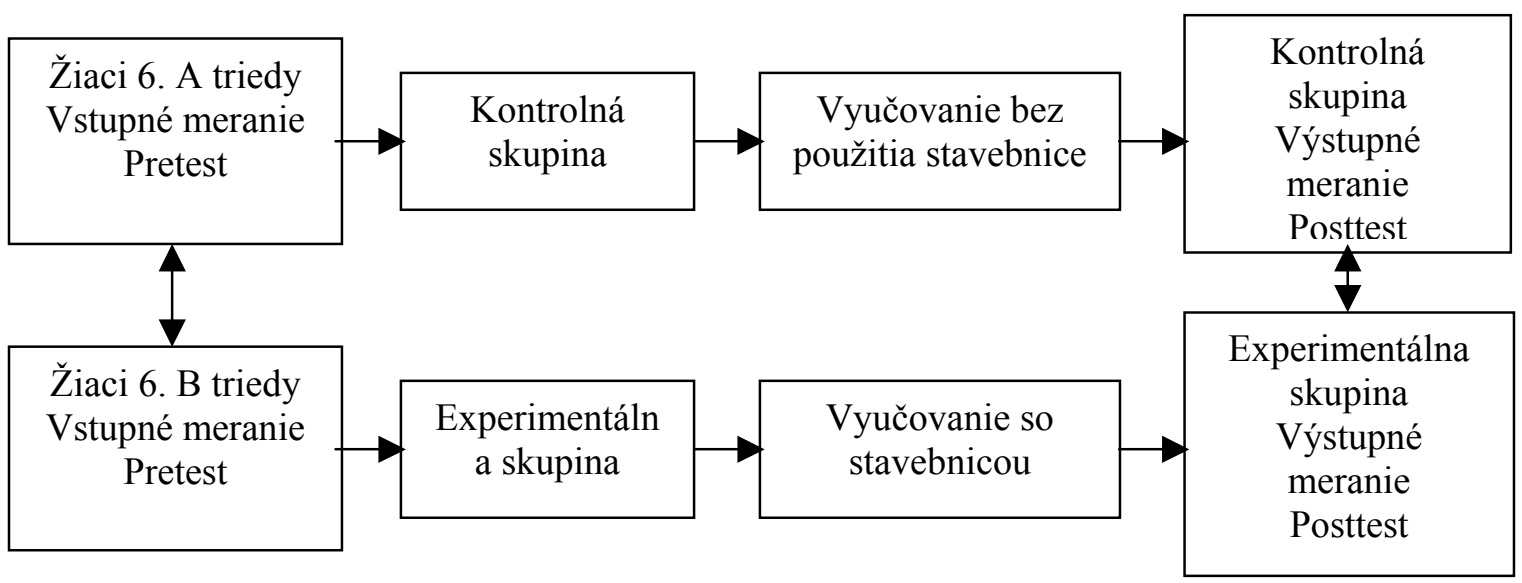

Pretest - vstupný TDS - PV $\quad$ Posttest - výstupný TDS - PV

\section{Obrázok 1: Schematické zobrazenie overovania H3}

$\mathrm{V}$ tomto prípade sme použili meranie na začiatku v 6.A a v 6.B triede a na konci výskumu $\quad \mathrm{v}$ experimentálnej a v kontrolnej skupine. Schematické zobrazenie overovania hypotézy H3 je na obrázku č. 1 .

Pred začatím pedagogického experimentu sme pomocou vstupného štandardizovaného Testu diferenciácie schopností - priestorové vzt'ahy (TDS-PV) zist'ovali, či je úroveň priestorovej predstavivosti žiakov 6.A triedy a 6.B rovnaká, či pochádzajú $z$ toho istého základného súboru. Celkový počet bodov, ktoré mohli žiaci v teste dosiahnut' bol 60 , počet úloh bol 60. Hypotézu o rovnosti priestorovej predstavivosti žiakov 6.A a 6.B triedy sme overovali pomocou KolmogorovhoSmirnovovho testu pre dva nezávislé výbery. Výsledky porovnania úrovne priestorovej predstavivosti žiakov 6.A a 6.B triedy sú spracované v tabul'ke č. 1 .

Tabul'ka 1: Výsledky výberovej skupiny na začiatku experimentu.

\begin{tabular}{|r|r|}
\hline & Testovacie štatistiky \\
\hline $\mathrm{D}$ & 0,25714 \\
\hline $\mathrm{z}$ & 1,521 \\
\hline $\mathrm{p}$ & 0,0200 -nevýzn. \\
\hline
\end{tabular}

D - testovacia charakteristika Kolmogorovho testu $\mathrm{z}$ - hodnota testovacieho kritéria

$\mathrm{p}$ - hodnota pravdepodobnosti nevýzn. - rozdiel nie je štatisticky významný na $\underline{\text { hladine významnosti } \alpha=0,01}$

Tabul'ka 2: Štatistické parametre aritmetický priemer a smerodajná odchýlka v 6.A. a v6.B triede.

\begin{tabular}{|l|l|l|}
\hline Skupina & AM & SD \\
\hline 6. A trieda & 19,929 & 9,935 \\
\hline 6. B trieda & 15,300 & 8,832 \\
\hline
\end{tabular}

AM - aritmetický priemer

SD - smerodajná odchýlka

Z tabul'ky 1 vidiet', že vypočítaná hodnota pravdepodobnosti $p$ je väčšia ako zvolená hladina významnosti 0,01 . Na zvolenej hladine významnosti 0,01 to znamená, že nie je štatisticky významný rozdiel vo vedomostnej úrovni žiakov v predmete technická výchova $\mathrm{v}$ preteste. $\mathrm{Z}$ tabuliek 1 a 2 je vidiet' mierny rozdiel i ked' nie významný na hladine významnosti 0,01 v prospech 6.A triedy. $\mathrm{Z}$ tohto dôvodu sme ako experimentálnu skupinu určili 6.B triedu. Výsledky riešenia vstupného testu TDS-PV v 6.A triede prehl'adne 
prezentuje graf č. 1 a v $6 . B$ triede graf č. 2 .

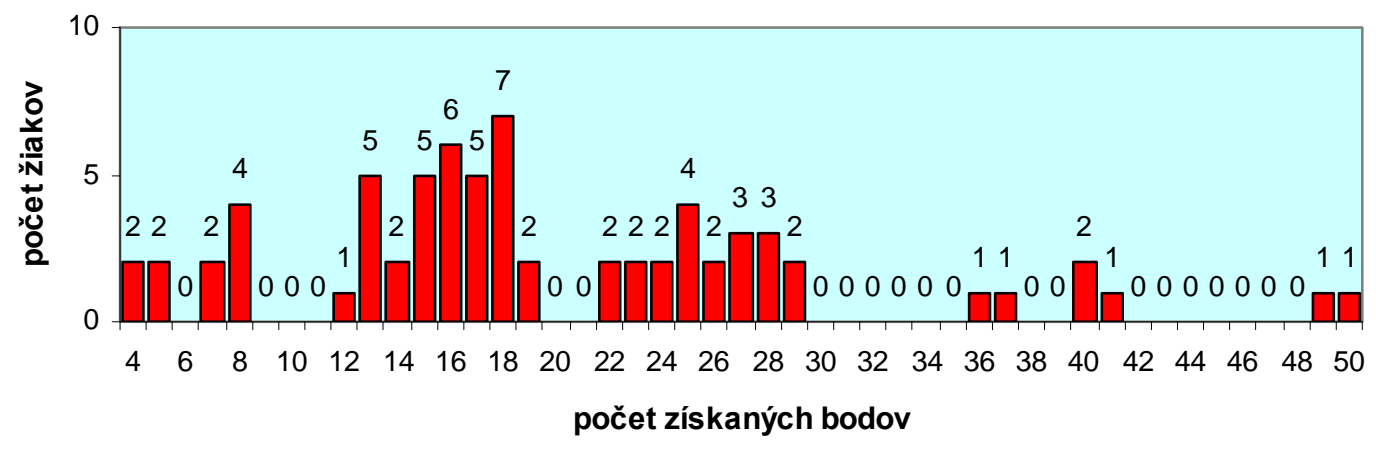

Graf 1: Frekvencia výskytu dosiahnutých bodov vo vstupnom teste TDS-PV v 6.A triede.

V rámci kvalitatívnej analýzy môžeme výsledky v triede 6.A zo vstupného testu charakterizovat' nasledovne:

Úspešnost' riešenia sa nám pohybovala v prvej polovici od 0 do 30 bodov zo 60 bodovej hodnotiacej škály testu. Vel'mi nízke hodnoty v rozmedzí $2-8$ bodov dosiahlo 10 žiakov, 12 až 19 bodov získalo 33 žiakov, čo je podpriemerný výkon. Skupina 20 žiakov získala od 22 do 29 bodov, čo je priemerný výkon, ale zostupným smerom k horším výkonom. Len malá skupina 7 žiakov dosiahla nadpriemerné výkony s počtom $36,37,40,41$, 49 a 50 dosiahnutých bodov hodnotiacej škály.

$\mathrm{Na}$ základe vyššie uvedenej kvantitatívnej analýzy možno konštatovat', že úlohy ktoré boli l'ahšie a menej náročné žiaci vedeli riešit', naopak náročnejšie a vel'mi náročné úlohy žiaci riešit' nevedeli. Výsledok sme $v$ podstate očakávali jednak preto, že žiaci nemajú rozvinutú priestorovú a plošnú predstavivost' natol'ko, aby boli $\mathrm{v}$ teste úspešní a dosahovali priemerné a nadpriemerné výkony. Možno to pripísat' aj tradičnému vyučovaniu, kde učitel' pri preberaní i upevňovaní nového učiva používa len učebnicu a nemá vel'a možností, aby priestorovú a plošnú predstavivost' mohol u žiakov rozvíjat' a upevňovat'. Výsledky dosiahnuté v celom spektre bodovej škály mohol ovplyvnit' aj didaktický test, s ktorým sa žiaci prvýkrát stretli, ale tieto podmienky mala aj trieda 6.B, ktorej výsledky sú zobrazené v grafe č. 2 .

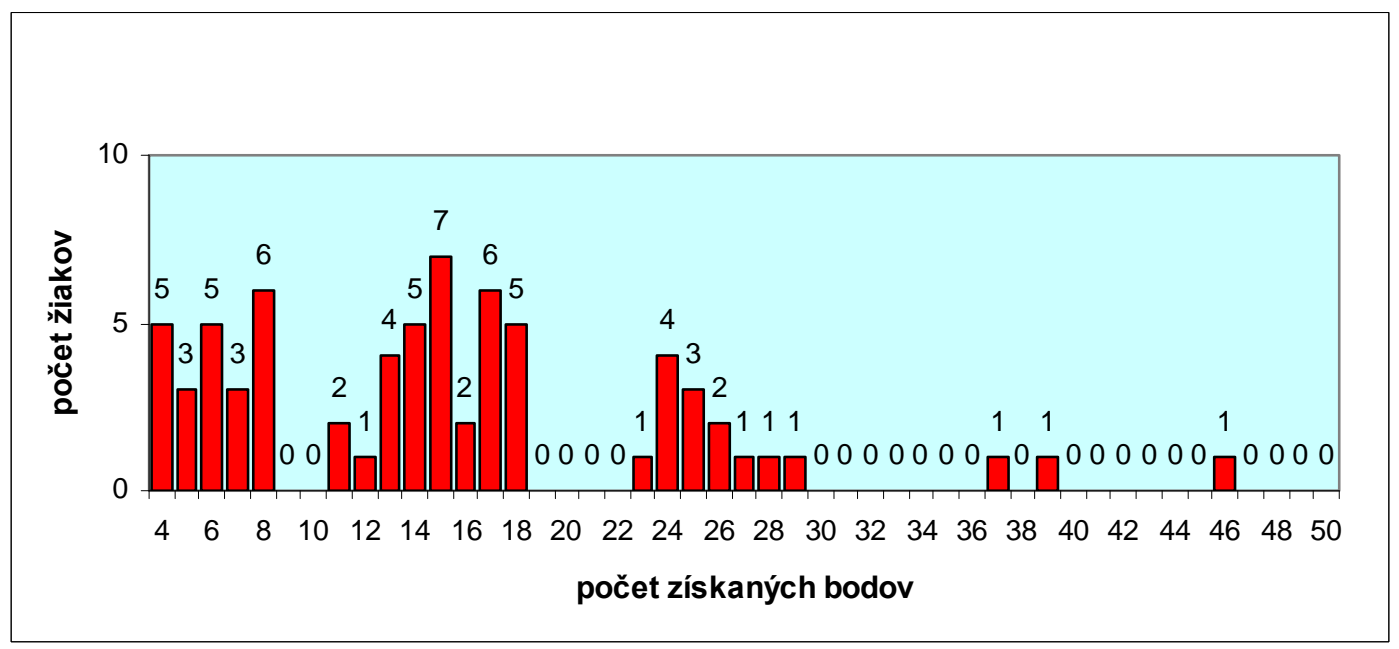

Graf 2: Frekvencia výskytu dosiahnutých bodov vo vstupnom teste TDS-PV v 6.B triede.

V 6.B triede úspešnost' riešenia úloh sa rovnako ako $\mathrm{v} 6$. A pohybovala $\mathrm{v}$ prvej polovici od 0 do 30 bodov, ojedinele 3 žiaci za hranicou 30 bodov. Ako vidiet' $\mathrm{z}$ grafu 12, najväčšia 
frekvencia výskytu je v oblasti do 18 bodov, 22 žiakov dosiahlo 4 až 8 bodov, 32 dosiahlo 11 až 18 bodov zo 60 bodovej škály daného testu. To znamená, že 22 žiakov dosiahlo vel'mi nízke hodnoty, 32 žiakov dosiahlo podpriemerné výkony. Skupina 13 žiakov dosiahla hodnoty 23 - 29 bodov, teda sú to výkony žiakov okolo priemeru, ale tak ako v 6 . A triede smerujúce k horším výkonom. Len 3 žiaci dosiahli nadpriemerné výkony. Porovnanie výsledkov zo vstupného testu medzi triedami 6.A a 6.B je zobrazené v grafe č. 3, z ktorého vidíme, že je len minimálny rozdiel vo frekvenciách dosiahnutých bodov danej hodnotiacej škály. Ide takmer o identické výkony, s tým, že lepšie výkony sú v prospech triedy $6 . \mathrm{A}$, voblasti nadpriemerných výkonov. $\mathrm{Z}$ tohto dôvodu sme 6.A triedu určili ako kontrolnú skupinu. Zist'ovali sme, či tento rozdiel je štatisticky významný na hladine významnosti 0,01 . Výsledky sú uvedené $\mathrm{v}$ tabul'ke 1.

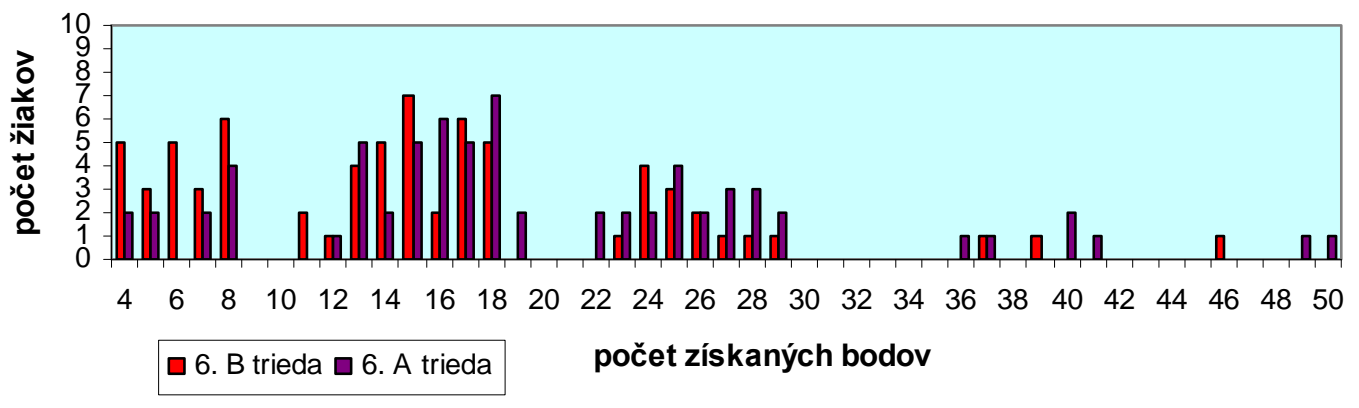

Graf 3: Porovnanie frekvencii dosiahnutých bodov vo vstupnom teste TDS-PV medzi medzi triedou 6. A a triedou 6. B.

Naším ciel'om bolo zistit', či na konci experimentu bude alebo nebude štatisticky významný rozdiel $\mathrm{v}$ úrovni priestorovej predstavivosti kontrolnej a experimentálnej skupiny.

Po aplikovaní stavebnice Dominika $\mathrm{v}$ predmete Technická výchova $\mathrm{v} 6$. ročníku základných škôl, sme overovali úroveň priestorovej predstavivosti žiakov kontrolných a experimentálnych skupín pomocou výstupného testu. Výstupný test pozostával zo 60 úloh a najvyššie skóre, ktoré mohli žiaci v Teste diferenciácie schopností - Priestorové vzt'ahy dosiahnut' bolo 60 bodov. Potom sme pomocou Kolmogorovho - Smirnovovho testu zist'ovali, či je medzi skupinami rozdiel na konci experimentu $\mathrm{v}$ prospech experimentálnej skupiny.

Testovanou hypotézou je nasledujúca nulová hypotéza.

$\mathrm{H}(0)$ : Medzi rozloženiami výkonov nie je významný rozdiel.

Nulovú hypotézu budeme testovat' oproti alternatívnej hypotéze:

$\mathrm{H}(1)$ : Medzi rozloženiami výkonov je významný rozdiel - rozloženie v experimentálnej skupine bude posunuté smerom $k$ vyššim bodovým hodnotám.

Tabul'ka 3: Výsledky vkontrolnej a experimentálnej skupine na konci experimentu.

\begin{tabular}{|l|r|}
\hline & Testovacie štatistiky \\
\hline $\mathrm{D}$ & 0,68571 \\
\hline $\mathrm{z}$ & 4,057 \\
\hline $\mathrm{p}$ & $0,0000^{* *}$ \\
\hline
\end{tabular}

D - testovacia charakteristika Kolmogorovho testu

$\mathrm{z}$ - hodnota testovacieho kritéria

$\mathrm{p}$ - hodnota pravdepodobnosti

** - rozdiel je štatisticky významný na hladine významnosti $\alpha=0,01$

Tabul'ka 4: Štatistické parametre aritmetický priemer a smerodajná odchýlka vkontrolnej $a$ v experimentálnej skupine.

$\mathrm{AM}$ - aritmetický priemer

SD - smerodajná odchýlka

\begin{tabular}{|l|l|l|}
\hline Skupina & AM & SD \\
\hline Kontrolná & 22,114 & 12,380 \\
\hline Experimentálna & 44,857 & 12,127 \\
\hline
\end{tabular}


Z tabul'ky č. 3 vidíme, že situácia vo výstupnom teste je jednoznačná. Rozdiel v dosiahnutých výsledkoch vo výstupnom teste medzi experimentálnou a kontrolnou skupinou je štatisticky významný na hladine významnosti 0,01 v prospech experimentálnej skupiny. To znamená, že ak učitel' bude učit' danú problematiku s použitím učebnice a stavebnice Dominika, s $99 \%$ pravdepodobnost'ou bude úspešnost' žiakov v danom ročníku ovplyvnená práve týmto didaktickým prostriedkom. Teda úspešnost' žiakov v danej oblasti nie je daná náhodným vplyvom, ale zákonitým použitím učebnice a stavebnice.

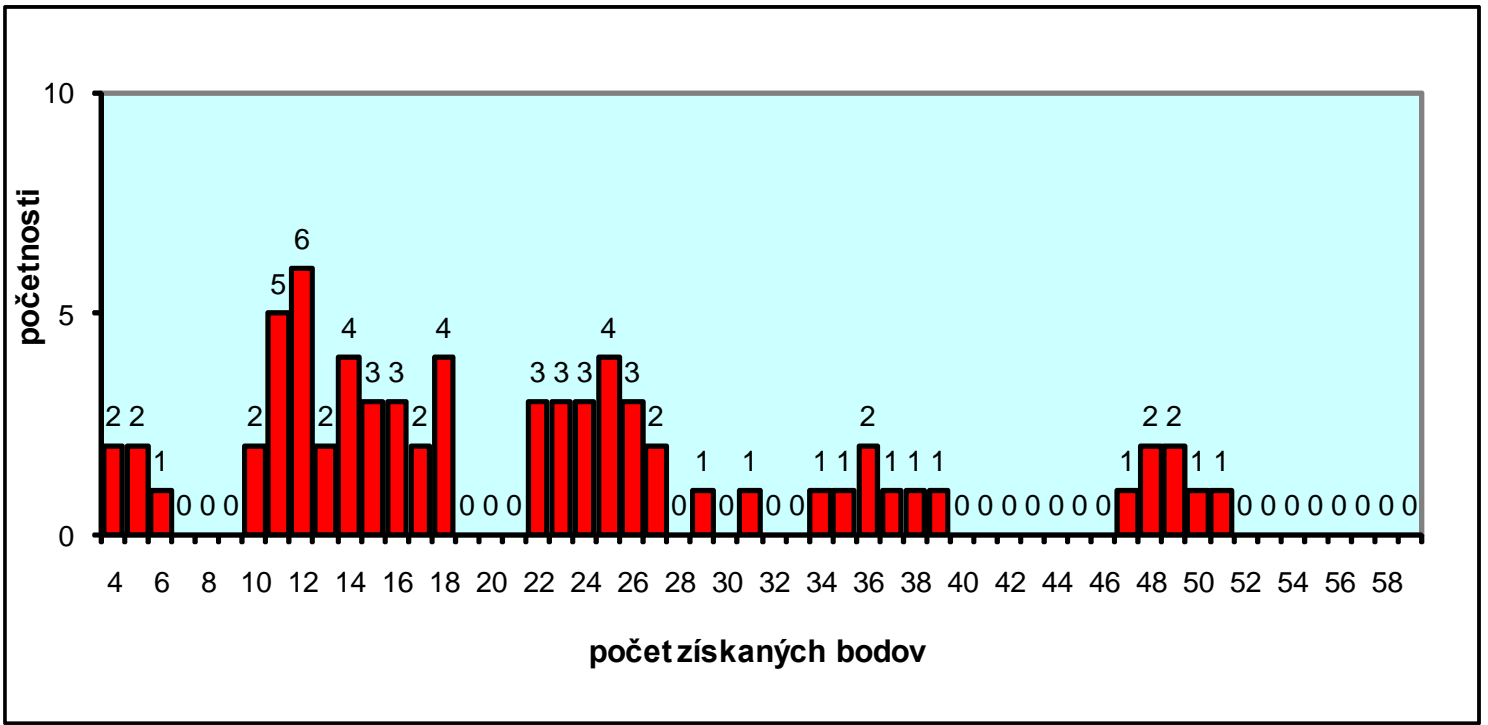

Graf 4: Frekvencia výskytu dosiahnutých bodov vo výstupnom teste TDS-PV v kontrolnej skupine.

Vo výstupnom teste sa u žiakov v kontrolnej skupine úspešnost' riešenia úloh pohybovala rovnako ako vo vstupnom teste v prvej polovici od 0 do 30 bodov, 5 žiaci získali vel'mi nízke hodnoty od 4 do 6 bodov, 31 žiakov dosiahlo podpriemerné výkony v rozmedzí $10-18$ bodov. Skupina 27 žiakov priemerné výkony, z nich 8 žiakov od 31 do 39 bodov, ostatní 19 žiaci od 22 do 29 bodov. Nadpriemerné výkony 47 - 51 bodov dosiahlo 7 žiakov. Vyučovanie bolo tradičné, štandardné s využitím stavebnice.
Výsledky možno povedat' sme očakávali lepšie, väčšiu frekvenciu úspešnosti sme očakávali okolo priemeru. I ked' sa nám okolo priemeru vyskytujú početnosti kladných odpovedí, najpočetnejšia skupina je stále len $\mathrm{v}$ pásme podpriemeru. Tým sa nám potvrdzuje predpoklad, že dané učivo je potrebné vyučovat' nielen sučebnicou, ale využívat' aj iné interaktívne učebné prostriedky s ciel'om precvičovat' predstavivost' a technické tvorivé myslenie.

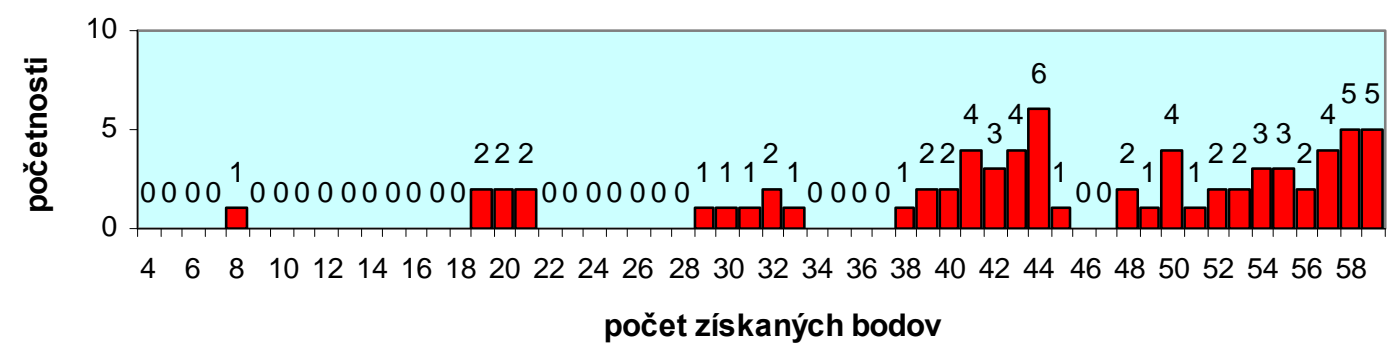

Graf 5: Frekvencia výskytu dosiahnutých bodov vo výstupnom teste TDS-PV v experimentálnej skupine. 
Vo výstupnom teste sa u žiakov v experimentálnej skupine úspešnost' riešenia úloh pohybovala $\mathrm{v}$ druhej polovici zo 60 bodovej škály testu. Podpriemerné hodnoty dosiahlo 7 žiakov, $\mathrm{z}$ nich 1 žiak 8 bodov a 6 žiaci od 19 do 21 bodov. Výkony okolo priemeru 29 - 33 bodov dosiahlo 6 žiakov. Najväčšia skupina 57 žiakov dosiahla nadpriemerné výkony v rozmedzí od 38 do 59 bodov. $Z$ tejto skupiny sa 26 žiakov pohybovalo v rozmedzí 48 - 59 bodov, zatial' čo $\mathrm{v}$ kontrolnej skupine takúto úspešnost' nezískal ani jeden žiak. Z Z grafu 15 vidiet' významné zlepšenie riešenia výstupného testu experimentálnou skupinou, v porovnaní s grafom 4. Pri porovnaní kontrolnej a experimentálnej skupiny možno konštatovat', že dosiahnutý rozdiel je v prospech experimentálnej skupiny. Tento rozdiel $\mathrm{v}$ dosiahnutých výsledkoch medzi kontrolnou a experimentálnou skupinou pripisujeme použivaniu stavebnice Dominika pri vysvetl'ovaní a upevňovaní nového učiva. Žiaci v experimentálnej skupine sa lepšie oboznámili s rôznymi tvarmi stavebnicových prvkov, lepšie si uvedomovali ich tvary a rozvíjala sa u nich lepšie technická predstavivost' ako u žiakov v kontrolnej skupine, ktorí pracovali len $\mathrm{s}$ učebnicou. Porovnanie obidvoch skupín nám uvádza graf č. 6, z ktorého jasne vyplýva daný rozdiel. Pre signifikantnost' tohto rozdielu sme zist'ovali, či tento rozdiel je štatisticky významný na hladine významnosti $0,01$. Výpočtom sme zistili, že tento rozdiel je štatisticky významný v prospech experimentálnej skupiny s tým, že tento rozdiel nie je náhodný, ale je zákonitý, spôsobený jednoznačne nami navrhnutou a použitou stavebnicou Dominika.

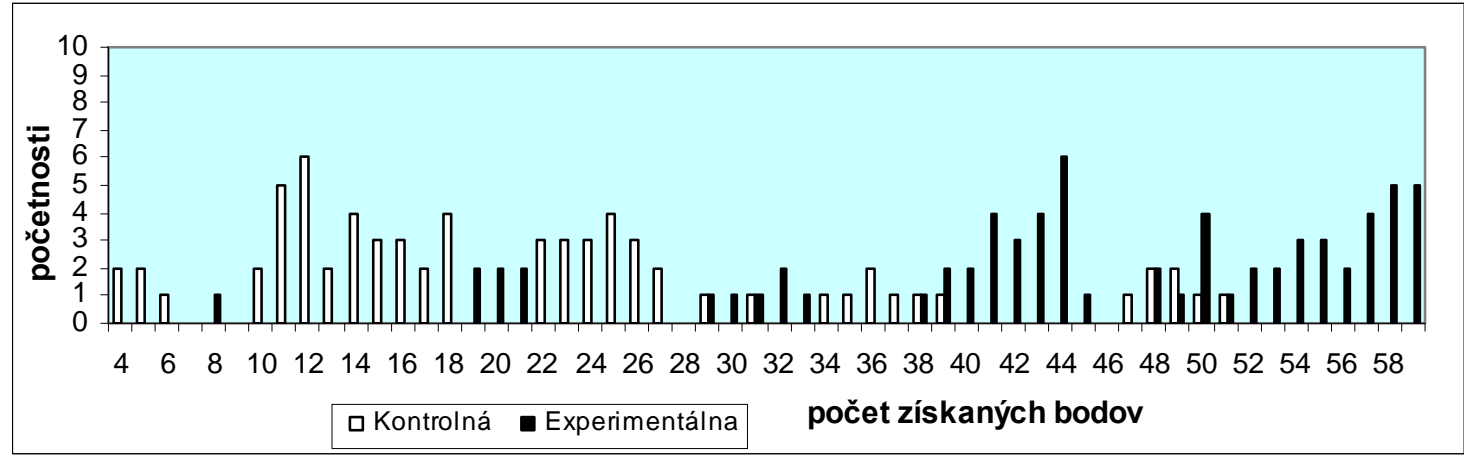

Graf 6: Porovnanie frekvencii dosiahnutých bodov vo výstupnom teste medzi kontrolnou a experimentálnou skupinou.

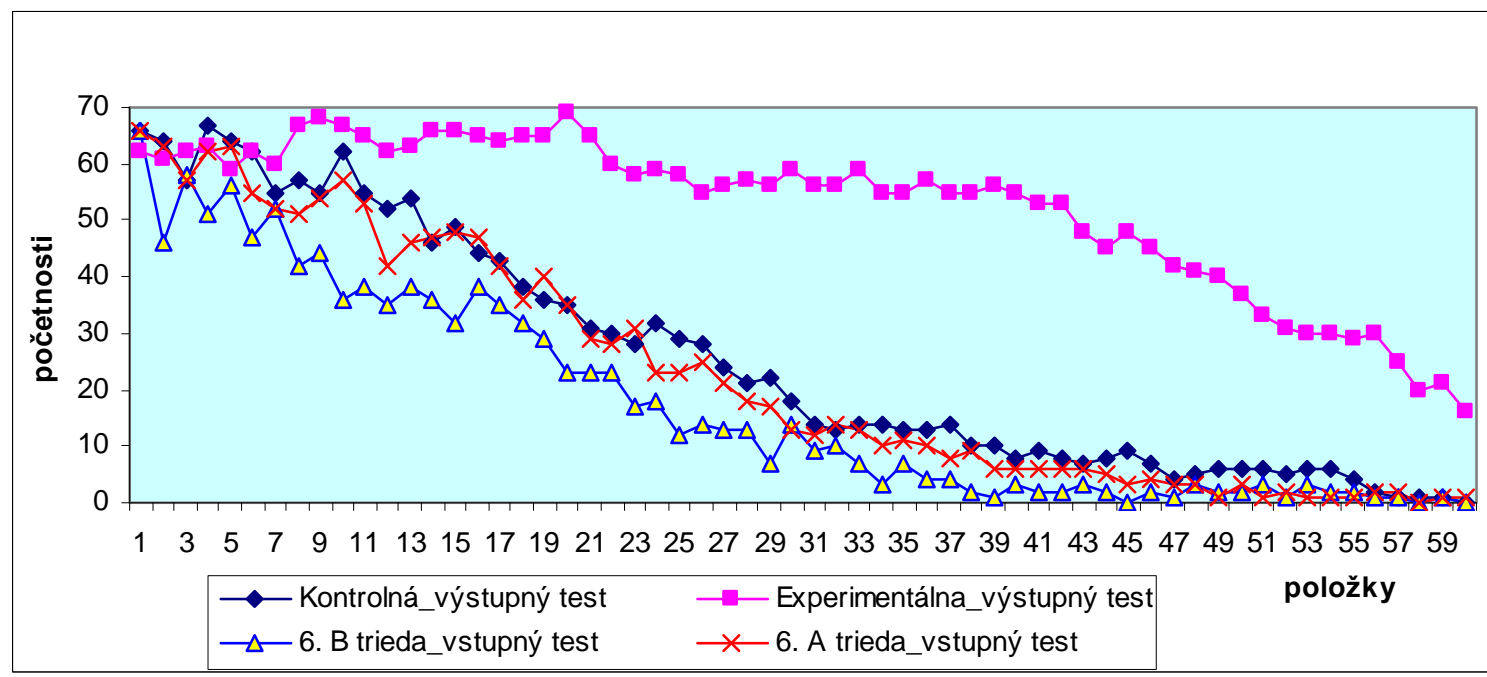

Graf 7: Porovnanie dosiahnutých úspešností riešenia jednotlivých položek vo vstupnom teste a vo výstupnom teste medzi žiakmi v kontrolnej a v experimentálnej skupine. 
Vidíme, že grafy ako aj aritmetické priemery ukazujú posun $\mathrm{v}$ smere $\mathrm{k}$ vyšším bodovým hodnotám. Môžeme konštatovat', že hypotéza H3 sa potvrdila. Práca so stavebnicou Dominika štatisticky významne ovplyvnila úroveň priestorovej predstavivosti v experimentálnej skupine.

\section{Záver}

Na základe analýzy skúmanej problematiky na základných školách, pri ktorej sme sa zamerali predovšetkým na zaradenie stavebnice Dominika v rámci zvýšenia efektivity do výučby, sme zistili, že žiaci 6. ročníka, ktorí používali stavebnicu Dominika dosiahli vo výstupnom teste TDS-PV významne lepšie výsledky ako žiaci, ktorí so stavebnicou Dominika nepracovali. Výsledky z pedagogického výskumu ukázali, že stavebnica Dominika rozvíja technické tvorivé myslenie, technickú predstavivost' a priestorovú predstavivost'.

$\mathrm{Na}$ rozdiel od preberania učebnej látky prostredníctvom výkladu učitela, ktorý bol podporovaný používaním stavebnice a kreslením učitel'a na tabul'u, pri ktorom boli žiakom odovzdávané hotové informácie a žiaci boli väčšinou len pasívnymi prijímatel'mi informácií, pri uplatnení metodiky práce so stavebnicou Dominika, žiaci samostatne riešili zadanú úlohu, či problém. Mali možnost' aktívne sa zapájat' do vyučovania a konzultovat' riešenie sučitel'om priamo na vyučovacej hodine.

Veríme, že aj výsledky nášho pedagogického výskumu budú inšpirovat' učitel'ov k akceptácii hračiek ako efektívnych výchovných prostriedkov a prostriedkov výchovy k tvorivosti a v rámci svojich kompetencií budú využívat' hračky vo vyučovaní.

\section{Literatúra}

(1) AUTIO, O.; HANSEN, R.: Defining and Measuring Technical Thinking: Students'Technical Abilities in Finnish
Comprehensive Schools. Journal of Technology Education, 14, 2002, č. 1, s. 5 - 19. ISSN 8085162-37-7.

(2) BALÁŽOVÁ, E.: Hračky v škole. Banská Bystrica: VH, 2004. ISBN 80-968131-3-7

(3) FURMANEK, W.; WALAT, W.: Przewodnik metodyczny dla nauczycieli techniki - informatyki. 1. Wyd. Rzeszów: Wydawnictwo Oświatowe FOSZE, 2002. ISBN 83-88845-08-X.

(4) GAVORA, P.: Úvod do pedagogického výskumu. Bratislava: UK, 2001. ISBN 80-2231628-8.

(5) KERLINGER, F. N.: Základy výskumu chování. Praha: Academia, 1972. Bez ISBN

(6) KOŽUCHOVÁ, M.: Obsahová dimenzia technickej výchovy. Bratislava: UK, 2003. ISBN 80-223-1747-0.

(7) KUZMA J.: Vzdelávaci štandard s exemplifikačnými úlohami z technickej výchovy - technickej zložky pre 2. stupen̆ základnej školy. Bratislava: MŠ SR, 2002.36 s. [dostupné na internete]

(8) LATIPKA, M.: Tvorba a použitie didaktických testov. Bratislava: SPN, 1988. ISBN 80-08-00782-6.

(9) PAVELKA, J.: Technická výchova a požiadavky na kvalitu edukácie. In Modernizace vysokoškolské výuky technických předmětů. Hradec Králové: PF, 2004.

(10) ZELINA, M.: Teórie výchovy alebo hladanie dobra. Bratislava: SPN, 2004. ISBN 80-10-00456-1.

PaedDr. Ludovít Polčic, PhD.

Univerzita Mateja Bela

Fakulta prírodných vied

Tajovského 40

97401 Banská Bystrica

Slovenská republika

tel.: +421 484467217

Fax: + 421484138643

E-mail: polcic@fpv.umb.sk 